\title{
ON THE IDENTITY OF PHYSCOMITRIUM MARTIANOVII (FUNARIACEAE, BRYOPHYTA)
}

\author{
E. A. IGNATOVA ${ }^{1} \&$ M. S. IGNATOV ${ }^{2}$ \\ ЧTO TAKOE PHYSCOMITRIUM MARTIANOVII \\ (FUNARIACEAE, BRYOPHYTA)?
}

Е. А. ИГНАТОВА ${ }^{1}$ И М. С. ИГНАТОВ ${ }^{2}$

Abstract

\begin{abstract}
The study of type collections of Physcomitrium martianovii Broth. ex Abramov reveals that it is a synonym of Entosthodon hungaricus (Boros) Loeske. However, the type of Physcomitrium martianovii var. majus is Physcomitrium pyriforme (Hedw.) Brid. A description and illustrations of the type material are provided.
\end{abstract}

Резюме

Изучение типового материала показало, что Physcomitrium martianovii Broth. ex Abramov является синонимом Entosthodon hungaricus (Boros) Loeske. При этом, однако, Physcomitrium martianovii var. majus Broth. ex Abramov относится к Physcomitrium pyriforme (Hedw.) Brid. Приводятся иллюстрации и описание типового материала.

In the second volume of "Novosti Sistematiki Nizhshikh Rastenij" (Novitates Systematicae plantarum non vascularum), which was labelled as ' 1965 ', there was published a paper of V. F. Brotherus (b. 1849 - d. 1929) with the description of several new taxa, including Physcomitrium martianovii and P. martianovii var. majus (Brotherus, 1965). Descriptions of these taxa were taken from a manuscript, fragmentarily preserved in the Komarov Botanical Institute after the Second World War. Most probably this was a manuscript addressed to Fedtshenko, who had begun to publish his multivolumed Flora of Asiatic Russia (in Russian), and for whom Brotherus was invited to work on the mosses. The first and second parts of the 'Mosses' in the Flora of Asiatic Russia appeared in 1914 and 1918, and the third part was published after Brotherus death, in 1931 (Brotherus, 1914, 1918, 1931). These three parts covered the families Andreaeales to Encalyptaceae, thus appearing immediately prior to the Funariaceae according to the "Brotherus system" (Brotherus, 1924). The authority of both Phy- scomitrium martianovii and its var. majus was attributed to Brotherus (Crosby \& al., 1992; database of Missouri Botanical Garden: http:// www.mobot.org/Pick/Search/most.html), although the actual decision to validly publish these taxa (as said in the original paper) was done by the Cryptogamic Department of the Komarov Botanical Institute. That department was headed at that time by V. P. Savicz, who studied algae and lichens, whereas the Laboratory of Bryology and Lichenology in that department was headed by I. I. Abramov, who also edited the bryological part of "Novosti Sistematiki Nizhshikh Rastenij". The description of Brotherus' long-posthumous new taxa also included illustrations, prepared by the technician of the Cryptogam department A. P. Sharikova, presumably under the supervision of I. I. Abramov. Thus the correct author citation, according to Article 46 of the International Botanical Code (Greuter, 2000), should be P. martianovii Broth. ex Abramov, and the same for var. majus.

Our study of the holotypes of two these taxa in Brotherus' Herbarium in Helsinki University, reveals

\footnotetext{
1 - Department of Geobotany, Biological Faculty, Moscow State University, Moscow 119899 Russia - Россия 119899, Москва, Московский университет, Биологический факультет, каф. геоботаники

2 - Main Botanical Garden of Russian Academy of Sciences, Botanicheskaya 4, Moscow 127276 Russia - Pоссия 127276 Москва, Ботаническая 4, Главный ботанический сад РАН
} 


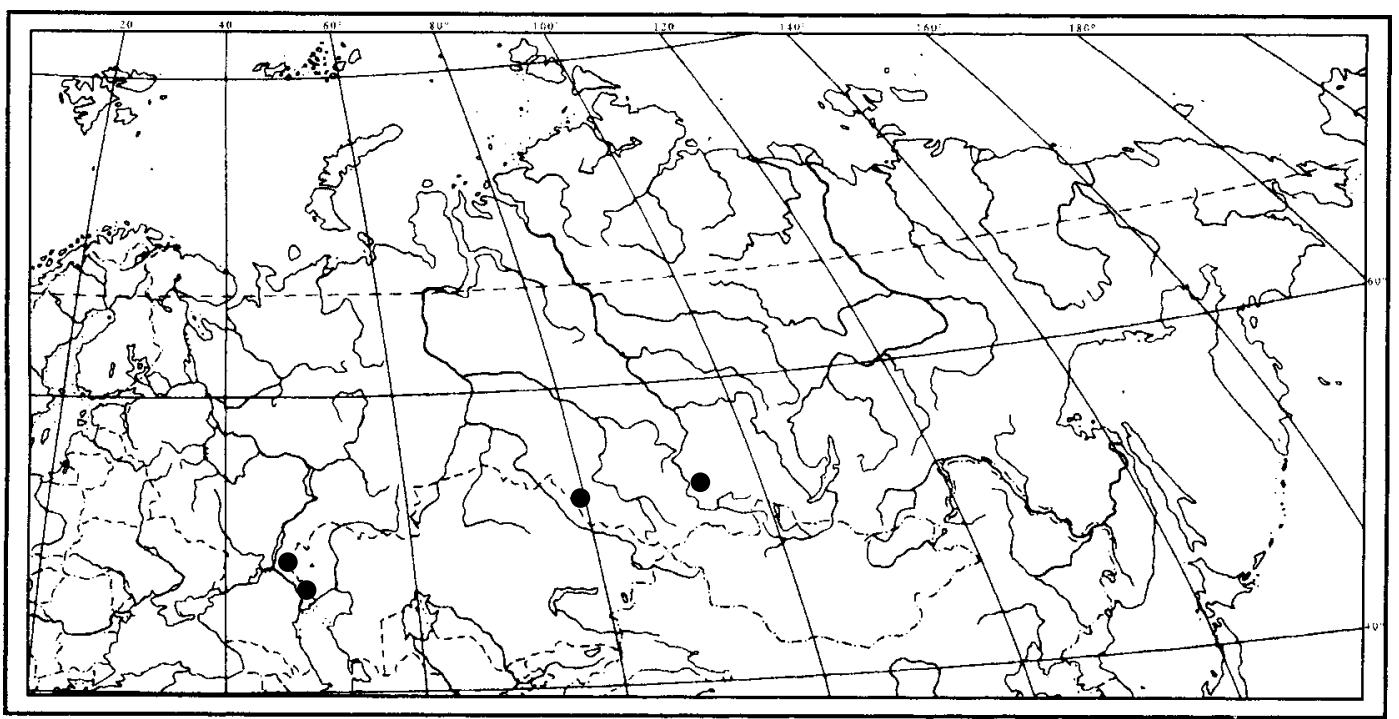

Fig. 1. Distribution of Entosthodon hungaricus (Boros) Loeske in Russia.

that the holotype of $P$. martianovii has elongate and thick-walled exothecial cells, characteristic for the genus Entosthodon (Fig. 2F). At the same time, $P$. martianovii var. majus has exothecial cells quite normal for the genus Physcomitrium: short rectangular, with moderately incrassate cell walls.

Plants of the holotype of $P$. martianovii are rather small for Physcomitrium pyriforme (with which it was compared in the original description), but are of a size normal for most Entosthodon species. Other diagnostic characters of $P$. martianovii (entire or subentire leaves and spores 25-28 $\mu \mathrm{m}$ in diameter) are also all in agreement with E. hungaricus. The latter species is distributed mainly in southern Europe, but recently it was found as new for Asia in the lowland steppes of Altaisky Territory (Pisarenko \& al., 2001). The type locality of $P$. martianovii is the second known locality of this species in Asia and the easternmost one (Fig. 1).

Entosthodon hungaricus (Boros) Loeske, Repert. Spec. Nov. Regni Veg. Sonderbeih. 3(2): 115. 1929. - Funaria hungarica Boros, Magyar Bot. Lapok 23 73. 1924.

Physcomitrium martianovii Broth. ex Abramov, Novosti Sistematiki Nizshikh Rastenii '1965': 273. f. 1. 1965, syn. nov. Holotype: "Si- biria, Minusinsk, 20.VIII.1887, leg. Martianoff s.n., (H-BR 3160007!).

Plants in loose tufts or growing as separate individuals, pale to yellowish- or grayish-green. Stems short, 1-1.5 mm, simple, erect. Lower leaves smaller, 1-1.5 mm long, ovate-lanceolate. Upper leaves few, erect when wet, slightly curved when dry, 3-3.5 mm long, ovate to obovate, shortly acute, and with narrow attenuate apiculus, slightly narrowed toward base, not decurrent, concave; margin plane, unbordered, in upper part slightly crenulate by upper cell angles; costa stout, ending below apex; laminal cells smooth, thin-walled, with few chloroplasts, in mid-leaf rectangular to short-rectangular, 40-65(-80) $\times 20-30 \mu \mathrm{m}$, at margins shorter, almost quadrate, below apex rhomboidal, towards base longer, in leaf base corners enlarged, 40-60×25$40 \mu \mathrm{m}$, forming small group. Autoicous. Seta stout, ca. $4 \mathrm{~mm}$ long, slightly twisted when dry. Lid small, almost plane, with short beak. Capsule brown, 1.5$2 \mathrm{~mm}$ long; erect, symmetric, oblong-clavate; neck narrow, slightly shorter than urn. Exothecium cells with very thick $(12-14 \mu \mathrm{m})$ cell walls, almost equal in width to lumen, below mouth transverse-rectangular in 3-5 rows, further below irregularly rounded and then elongate rectangular. Peristome

Fig. 2. A-O: Entosthodon hungaricus (Boros) Loeske (from the holotype of Physcomitrium martianovii Broth. ex Abramov, H) and P-R: Physcomitrium pyriforme (Hedw.) Brid. (from the holotype of Physcomitrium martianovii var. majus Broth. ex Abramov, H): A-E, P - habit; F - exothecial cells and spores; $\mathrm{G}$ - upper laminal cells; H-M - leaves; N - mid-leaf cells; O basal leaf cells; Q-R - capsules. Scale bars: $2 \mathrm{~mm}$ for A-E, P-R, $1 \mathrm{~mm}$ for H-M; $100 \mu \mathrm{m}$ for F-G; N-O. 


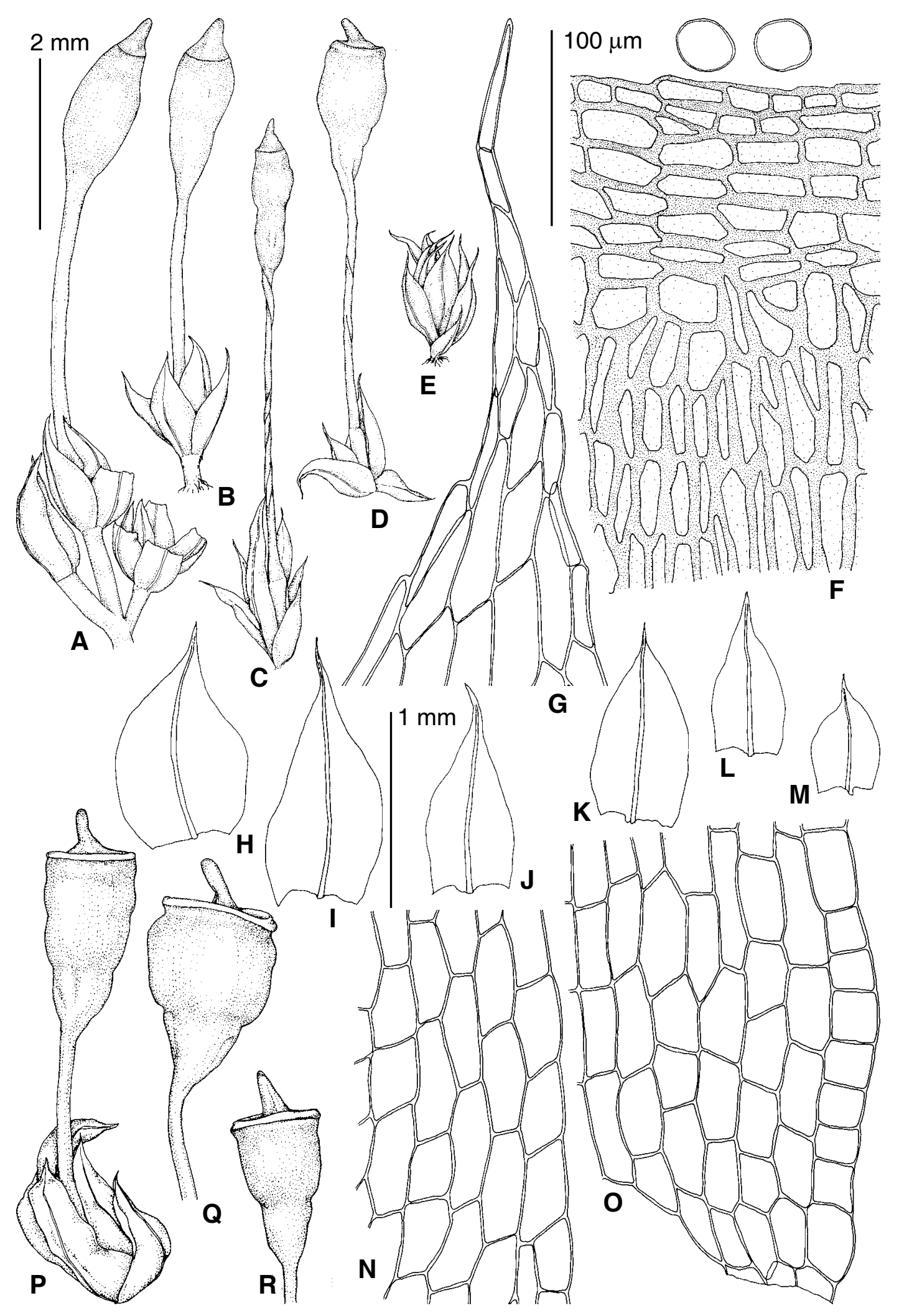


lacking. Spores brownish, papillose, 25-30 $\mu \mathrm{m}$. Calyptra large, in lower part swollen and lobed.

Entosthodon hungaricus was long considered endemic to southern Europe, but recently it was also found in North Africa, Morocco (Cano \& al., 1999), and in Central Asia, Altai (Pisarenko \& al., 2001). It is quite likely (cf. Fig. 1) that this species occurs in Kazakhstan and southern regions of West Siberia, an area poorely explored for bryophytes. Until now, however, E. hungaricus has not been found in Middle Asian collections (Abramov \& al., 1989). In European Russia this species was found so far only in the dry desert area to the east of the Volga River (Ignatov \& Ignatova, 2003; Suragina \& al., 2002). Pisarenko \& al. (2001) provided an overview of the distribution and ecology of E. hungaricus, one of few mosses that can tolerate high concentrations of $\mathrm{NaCl}$ in the soil.

Physcomitrium pyriforme (Hedw.) Hampe, Linnaea 11:80. 1837. - Gymnostomum pyriforme Hedw., Sp. Musc. Frond. 38. 1801.
Physcomitrium martianovii var. majus Broth. ex Abramov, Novosti Sistematiki Nizsikh Rastenii '1965': 274. 1965, syn. nov. Holotype: “Transbaikalia, distr. Verchneudinsk, ad Yamarovka, 23.VII.1911, P. Mikhno (H-BR 3160006!). - P. martianovii fo. majus (Broth.) Smirnova, Novosti Sistematiki Nizsikh Rastenii 6: 256. 1969 '1970'.

Most plants of the holotype are quite typical P. pyriforme: mature capsules have their characterisic shape (Fig. 2Q), and the exothecium is formed by shortly rectangular cells, i.e., typical for the genus Physcomitrium. Immature capsules are narrower (Fig.2P,R), somewhat resembling Entosthodon, but their exothecium is identical with that in typical 'pyriforme' capsules.

\section{ACKNOWLEDGEMENTS}

We are grateful to Jaakko Hyvönen and Sanna Huttunen for arranging of our visit to the H-BR Herbarium and to Bill Buck for correcting of English of the paper. The work of the first author was partly supported by RFBR grant 05-04-48780 and HШ7063.2006.4.

\section{LITERATURE CITED}

[ABRAMOV, I.I., A. L. ABRAMOVA \& I.V.SIROTINA] АБРАМОВ И.И., А. Л. АБРАМОВА, И.В. СИРОТИНА 1989. О видах рода Entosthodon Schwaegr. (сем. Funariaceae) из Средней Азии. - [About species of Entosthodon Schwaegr. (Funariaceae) from Middle Asia] Новости cист.низи.pacm. [Novosti Sist. Nizsh. Rast.] 26: 124-132.

[BROTHERUS, V. F.] БРОТЕРУC, В. Ф. 1914. Мхи (Andreaeales; Bryales, 1 часть). - [Mosses (Andreaeales; Bryales, 1st part)] В кн: Федченко, Б. А. (ред.) Флора Азиатской России. Часть 4. Петроград, Переселенческое управление [In: Fedtchenko, B. A. (ed.), Flora Asiatskoi Rossii. Pt. 4. Petrograd, Pereselencheskoe Upravlenie]: 1-78.

[BRotherUS, V. F.] БРОтеРуC, В. Ф. 1918. Мхи (Bryales, 2 часть). - [Mosses (Bryales, 2d part)] $В$ кн: Федченко, Б. А. (ред.) Флора Азиатской России. Часть 13. Петроград, Переселенческое управление [In: Fedtchenko, B. A. (ed.), Flora Asiatskoi Rossii. Pt. 13. Petrograd, Pereselencheskoe Upravlenie]: 79-182.

BROTHERUS, V. F. 1924. Musci. - In: Engler, A. \& Prantl, K. (eds.), Die Natuerlichen Pflanzenfamilien, ed. 2, W. Engelmann, Leipzig, 10: 1-478

[BROTHERUS, V. F.] БРОTЕРУC, В. Ф. 1931. Мхи Азиатской России (Bryales) часть III. - [Mosses of Asian Russia (Bryales) part 3] Tpyды бот. сада АН CCCP [Trudy Bot. Sada Akad. Nauk SSSR] 42(2): 141-180.

[BROTHERUS, V. F.] БРОТЕРУC, В. Ф. 1965. Новые виды мхов из Азиатской части СCCP. - [New species of mosses from the Asian Russia] Новости сист.низи.pacm. [Novosti Sist. Nizsh. Rast.] '1965': 273-277.

CANO, M. J., R. M. ROS, J. GUERRA \& J. GONZALEZ 1999. The identity of Entosthodon hungaricus (Boros) Loeske and E. maroccanus (Meyl.) Hebr. \& Lo Giudice (=Physcomitrium maroccanum Meyl.). - J. Bryol. 21: 67-70.

GREUTER, W. \& AL. (eds.) 2000. International Code of Botanical Nomenclature (Saint Louis Code) adopted by the Sixteenth International Botanical Congress, St. Louis, Missouri, July-August 1999. Koeltz Scientific Books, Koenigstein.

[IGNATOV, M.S. \& E.A. IGNATOVA] ИГНАTOB M, C., Е. А. ИГНАТОВА 2003. Флора мхов средней части Европейской России. Т. 1. - [Bryophyte flora of Middle Part of European Russia. Vol. 1] M., KMK, [Moskva, KMK], $608 \mathrm{pp}$.

PISARENKO, O. Yu., E. A. IGNATOVA, M. S. IGNATOV 2001. Entosthodon hungaricus (Boros) Loeske (Funariaceae, Musci) in Altaisky Territory, South Siberia. - Arctoa 10: $97-102$.

[SURAGINA, S. A., E. A. IGNATOVA, M. S. IGNATOV \& V. I. ZOLOTOV] СУРАГИНА, С. А., Е. А. ИГНАТОВА, М. С. ИГНАТОВ, В. И. ЗОЛОТОВ 2003 '2002'. Материалы к флоре мхов Астраханской области (юг европейской России). - [Contribution to the Moss Flora of Astrakhan Province (South European Russia)] Arctoa 11: $169-174$. 